\title{
Reflections on the Making of the Grand dictionnaire chinois-français contemporain
}

\author{
Jianhua Huang, Centre for Linguistics and Applied Linguistics, Guangdong \\ University of Foreign Studies, Guangzhou, China \\ and \\ Hai Xu, Centre for Linguistics and Applied Linguistics, Guangdong \\ University of Foreign Studies, Guangzhou, China \\ (Corresponding Author, xuhai1101@gdufs.edu.cn)
}

\begin{abstract}
This article discusses how the Grand dictionnaire chinois-français contemporain (GDCFC, 2014), one of the largest Chinese-French dictionaries, was designed and compiled. Due to the limited resources in the language pair of Chinese and French, GDCFC was designed as a bidirectional bilingual dictionary. To meet the needs of Chinese-speaking learners of French, the main user group, GDCFC extends the lemma list, and enriches the information of French equivalents in terms of their frequency, grammar and register. To be geared to the needs of French-speaking learners of Chinese, the secondary user group, GDCFC includes some headwords that fall into regional varieties of Chinese, and also provides useful information on the formulaicity and flexibility of Chinese characters (classifiers in particular). Some other features, such as the indication of POS and equivalents in context, and establishment of a semantic network of the nomenclature, were designed to benefit both groups of users. The making of this dictionary has implications for the compilation of other less-resourced bilingual dictionaries.
\end{abstract}

Keywords: CHINESE-FRENCH DICTIONARY, BIDIRECTIONAL, DESIGN FEATURES, USER NEEDS

Opsomming: Gedagtes oor die samestelling van die Grand dictionnaire chinois-français contemporain. Hierdie artikel bespreek hoe die Grand dictionnaire chinois-français contemporain (GDCFC, 2014), een van die grootste Chinees-Franse woordeboeke, ontwerp en saamgestel is. Weens die beperkte hulpbronne in die taalpaar Chinees en Frans, is die GDCFC as ' $n$ tweerigting- tweetalige woordeboek ontwerp. Om te voorsien in die behoeftes van Chineessprekende aanleerders van Frans, die hoofgebruikersgroep, het die GDCFC die lemmalys, sowel as die inligting oor Franse ekwivalente in terme van hul frekwensie, grammatika en register, uitgebrei. Om aan te pas by die behoeftes van Franssprekende aanleerders van Chinees, die sekondêre groep, het die GDCFC sommige trefwoorde wat geklassifiseer kan word as streeksvariante van Chinees ingesluit, en ook nuttige inligting oor die formulisme en plooibaarheid van Chinese karakters (in

A few of the ideas of this article were presented at the 11th International Conference of the Asian Association for Lexicography (ASIALEX), hosted by the Guangdong University of Foreign Studies in Guangzhou, Guangdong Province, China, 10-12 June 2017. 
die besonder klassifiseerders), verskaf. Sommige ander kenmerke soos die aanduiding van woordsoort en ekwivalente in konteks, en die daarstelling van 'n semantiese netwerk van terminologie, is ontwerp om albei gebruikersgroepe daarby te laat baat vind. Die samestelling van hierdie woordeboek het ook implikasies vir die samestelling van ander hulpbronbeperkte tweetalige woordeboeke.

Sleutelwoorde: CHINEES-FRANSE WOORDEBOEK, TWEERIGTING-, ONTWERPKENMERKE, GEBRUIKERSBEHOEFTES

\section{Introduction}

The project of the Grand dictionnaire chinois-français contemporain (GDCFC), which lasted 16 years ${ }^{1}$, was finally completed in October 2014 . With the coverage of more than 100,000 entries and over 100,000 illustrative examples, GDCFC is regarded as one of the largest Chinese-French dictionaries ever made. Since its publication, this dictionary has won public acclaim ${ }^{2}$. In this article, we discuss how GDCFC was designed and compiled to meet the needs of both Chinese-speaking learners of French and French-speaking learners of Chinese.

According to the theoretical principles of lexicography, a dictionary is supposed to be of a specific type, and responds to the needs of certain users in certain tasks, for example, the needs of reception, production or translation by L1/L2 speakers (Atkins and Rundell 2008: 40-43; Svensén 2009: 14-18; AdamskaSałaciak 2013: 216). In fact, different types of monolingual Chinese dictionaries as well as bilingual English ones have been published in China. However, as far as the language pair of Chinese and French is concerned, the number of L2 Chinese learners in French-speaking countries and L2 French learners in China is quite small, and the resources (including dictionaries available) ${ }^{3}$ for this language pair are quite limited. Therefore, from the start of the dictionary project, GDCFC was designed to be a versatile bilingual dictionary with "a fusion of reception-oriented and production-oriented information" (Hannay 2003: 149). Just as Szende (2006: 20) claimed when it was still in preparation, this ChineseFrench dictionary "vise à refléter la langue chinoise d'aujourd'hui dans toutes ses dimensions, intègre les besoins des deux publics et apporte différentes options de traduction, allant du sens littéral vers une expression authentiquement idiomatique".4

\section{Features designed for the main user group}

Since GDCFC was published in China, it is natural that priority was given to the needs of Chinese users, specifically those of adult learners of French and professional translators. Potential user situations include production in the foreign language (i.e. French) and translation into the foreign language (i.e. French), in addition to users' cognitive needs for foreign-language (i.e. French) learning (Tarp 2008). What this group of users need most is the availability of an extensive lemma list and rich information of French equivalents. 


\subsection{Extensive lemma list}

To list or not to list semi-fixed and free expressions in a dictionary is a thorny issue. On the one hand, because of their structure and meaning, those expressions do not gain the status of an independent headword. If the editorial team followed the principle of one Chinese-French dictionary and listed in the entries such expressions as "锅的容量" (the volume of a wok), "艺术家的书籍" (books by an artist), and "婚姻有效性的障碍" (a barrier to the validity of marriage), the dictionary macrostructure would be redundant and devoid of rule (Huang 2014). On the other hand, for the purpose of production or translation, users may wish to have access to a rendering of those frequent semi-fixed and free Chinese expressions.

Based on their frequency of usage, GDCFC provides as many useful Chinese expressions as possible in an entry, for example,

【工业】gōngyè industrie $f \triangleright$ 化学 industries chimiques \|轻（重） industrie légère (lourde) $\| \sim$ 设备 équipement industriel $\| \sim$ 体系 système industriel $\| \sim$ 城市 villes industrielles $\| \sim$ 区 une zone industrielle $\| \sim$ 产品 articles [produits] industriels $\| \sim$ 化学 chimie industrielle $\| \sim$ 美术 art industriel $\| \sim$ 技术 technique industrielle $\| \sim$ 污染 pollution industrielle $\| \sim$ 布局 répartition géographique des industries; répartition industrielle $\| \sim$ 界 monde industriel; milieu industriel $\| \sim$ 学校 école des arts et métiers; école polytechnique

The article【工业】consists of 14 subentries. Such an arrangement helps to expand, in a compact way, the number of useful multiword expressions in the dictionary.

To meet the production needs of users, GDCFC also enters approximately 3,000 new Chinese words or senses that occurred in recent years. Those neologisms have been strictly selected according to their frequency counts in Chinese language corpora as well as their established usages in some dictionaries of new words and phrases. For instance,

【房奴】 fángnú accros m.pl au [dépendants du, esclaves du] credit logement; individu ou ménage $m$ surendetté [écrasé par ses mensualités] de credit immobilier

【微信】 wēixìn WeChat (application de messagerie rapide pour téléphone mobile, «micro message»)

【银色人才】 yínsè réncái personne $f$ de talent à la retraite qui continue à contribuer à la vie en société

Undoubtedly, it would be untenable to clutter a dictionary with some "fad" words which would soon become obsolete.

Nowadays, a general-purpose dictionary cannot ignore scientific and technical terms, especially those that are used in everyday life. GDCFC is not 
an exception, and lists approximately 10,000 technical terms, for example,

【彩超】 căicāo [〈abrév.〉 pour 彩色多普勒超声] échographie $f$ Doppler couleur

【磁浮列车】cífú-lièchē train $m$ à lévitation magnétique

【云计算】yúnjìsuàn 【Inform. 』Informatique $f$ en nuage(s); infonuagique $f$; nuage $m$ informatique; calcul $m$ dématérialisé [dans les nuages]; informatique $f$ virtuelle [dématérialisée, dans le nuage]; le cloud computing (angl.)

GDCFC distinguishes itself from other dictionaries of the same type in that the selection of those entries has drawn on the expertise of a group of specialists from forty disciplines. It thus ensures the representativeness of those terms and the accuracy of their translations.

GDCFC also offers some colloquial expressions and slang, for example,

【倒贴】dàotiē 1 subventionner v.t au lieu d'en gagner 2 〈fam. > (femme amoureuse) fournir de l'argent à son amant

【粉丝 2 fěnsī $\langle$ fam.〉 fan $n$; admirat-eur(rice) $n$; groupie $f \triangleright$ 某歌星的 les fans d'une chanteuse étoile

Some of the expressions are not even available in the authoritative Contemporary Chinese Dictionary (CCD, 2012) and the Normative Dictionary of Contemporary Chinese (NDCC, 2014). They are included, for they could satisfy the needs of users with different kinds of sociolects.

GDCFC embraces in its lemma list some frequent abbreviations as well. For example,

【东盟】Dōngméng [〈abrév.〉 pour 东南亚国家联盟] Association de l'Asie du Sud-Est (ANASE) $\triangleright \sim$ 国家 pays de l'ANASE

【妇代会】 fùdàihuì [〈abrév.〉 pour 妇女代表大会] Assemblée $f$ des déléguées de femmes

【个唱】gèchàng [〈abrév.〉 pour 个人演唱会] concert $m$ donné par un seul chanteur [une seule cantatrice]; récital $m$

In brief, the reference needs of dictionary users can be largely satisfied by the complementary list of frequently-used semi-fixed/free Chinese expressions, neologisms, scientific/technical terms, colloquial expressions/slang, and common abbreviations.

\subsection{Common French equivalents}

In each article, GDCFC provides only common French equivalents to Chinese words or expressions, and carefully excludes rare or obsolete terms. In general, the vocabulary used in this dictionary does not exceed that in Le Petit Larousse (2013) or Dictionnaire du français contemporain (1980), except a small number of 
scientific and technical terms (cf. Cowie 1999; Xu 2012).

Consider the entry【傲然】. "Hautainement" is given as the first French equivalent in the Dictionnaire chinois-français (1990) and the Nouveau Dictionnaire pratique chinois-français (1996). But today this term is no longer mentioned in the contemporary French dictionaries, neither in Le Petit Larousse nor in Le Robert (1996). In its 1932-35 edition, the Dictionnaire de l'Académie française clearly indicates that the word "est peu usité" (is rarely used). Obviously, an equivalent such as "hautainement" would mislead Chinese users rather than helping them to master French. GDCFC instead offers some more common equivalents to【傲然】: fièrement adv; de manière hautaine [imposante]; avec fierté.

\subsection{Useful grammatical information of French equivalents}

Almost all existing Chinese-French general dictionaries, including Dictionnaire Ricci chinois-français (2014), do not offer grammatical information of French equivalents. Only the Dictionnaire chinois-français (1990) indicates the gender information (masculine or feminine) in the nouns of French translations, but it gives no clues for verbs and other word classes. In a dictionary targeting French native speakers, this information might be redundant. However, in a dictionary primarily for Chinese-speaking learners of French, the grammatical information is very useful and even indispensable. Therefore, GDCFC made an effort to explicate the grammatical functions of French translations. For instance,

【会面】 huì//miàn se rencontrer v.pr; se voir v.pr; rencontrer v.t; avoir une entrevue (avec qn); rencontre $f \ldots$

【远航】 yuănháng naviguer $v . i$ au long cours [sur un long parcours]; partir $v . i$ en expédition; navigation $f$ lointaine [hauturière, au long cours]...

【远客】 yuănkè (Q. 个、位) hôte $m$ (hôtesse $f$ ) [voyageu-r(se) $n$ ] qui vient de loin

【原初】yuánchū début $m$; au début loc.adv; à l'origine loc.adv; d'abord loc.adv

【原生】 yuánshēng primordial(e) $a$; protogène $a$; primiti-f(ve) $a$; proto- préf $\triangleright \sim$ 矿物minerais primitifs, minéral originel $\sim$ 植物 protophyte $m$

The grammatical information of French equivalents, such as gender of nouns $(m / f)$, transitivity of verbs $(v . i / v . t / v . p r)$, and subcategories of adjectives $(a)$ and adverbs (loc.adv), will help learners to produce grammatically correct French. Those syntactic codes might not appear user-friendly, but adult learners of French in China, the majority of users that this dictionary targets, are actually quite familiar with those codes as a result of their French grammar instruction at college. 


\subsection{Appropriate register of French equivalents}

More often than not, there are several possible translations ${ }^{5}$ of a word or phrase. While using a dictionary for production or translation, learners often ignore the register of an L2 word, and hence fail to use it appropriately. GDCFC fills this gap by briefly indicating the register of some French equivalents. For example,

【妓院】 jiyuàn（Q. 家、座） maison $f$ de prostitution; maison $f$ close; maison $f$ publique; bordel $m$ (fam.) • $\approx$ 娼家

【淫欲】yínyù lubricité $f$; désir $m$ impur [impudique, sexuel]; concupiscence $f$ (litt.) $\triangleright$ 饱暖思 Bien nourri et habillé, on commence à désirer la lubricité.

【怨恨】 yuànhèn (1 en vouloir à loc.v; garder rancune à loc.v; haïr v.t; abhorrer v.t (litt.) 2 ressentiment $m$, rancune $f$, rancœur $f$, haine $f$, animosité $f \triangleright$ 充满 être plein de haine

【带头】 dài//tóu prendre la tête de; donner l'exemple; prendre l'initiative de; mener la danse (péj.) $\triangleright$ 他 跳进水里。Il fut le premier à se jeter à l'eau. \| 作用 rôle de promoteur; exemple d'un pionnier; influence exercée par les initiateurs $\checkmark \sim$ 羊 sonnailler $m$ de troupeau $\| \sim$ 者 locomotive $f$ (fig.) $\bullet \approx$ 领头

In the above articles, the French equivalents "bordel" is marked with (fam.), "concupiscence" and "abhorrer" with (litt.), "mener la danse" with (pej.), and "locomotive" with (fig.). Those metalanguage labels help to prevent Chinese learners from using the French words inappropriately.

\section{Features designed for the secondary user group}

Due to a small number of L2 Chinese learners in French-speaking countries and limited resources of the Chinese-French language pair, publishers are reluctant to produce a Chinese-French dictionary exclusively for this group of users. Hence, GDCFC targets L2 Chinese learners as well, though as a secondary intended user group. Their potential user situations embrace reception of the foreign language (i.e. Chinese) and translation from the foreign language (i.e. Chinese), in addition to their cognitive need for foreign-language (i.e. Chinese) learning (Tarp 2008). This group of users may wish to obtain information on the usage of Chinese characters or words.

\subsection{Words in regional varieties of Chinese}

In addition to Putonghua (Mandarin Chinese), L2 Chinese learners are likely to encounter some words and phrases that are mainly used in Taiwan, Hong Kong, Macau or the overseas Chinese communities. To help users understand 
their meanings, GDCFC offers some of the most common nomenclature, and marks them with 〈dial.〉. For example,

【三脚猫】 sānjiăomāo 〈dial.〉 chat $m$ à trois pattes (trad. litt.); personne $f$ qui n'a que des connaissances superficielles, personne $f$ dénuée de compétence

【烧刀子】 shāodāozi 〈dial.〉 eau-de-vie $f$ forte

【失失慌慌】 shīshīhuānghuāng 〈dial. $\rangle \bullet \approx$ 慌张

【手袜】 shǒuwà $\langle$ dial. $\rangle \bullet=$ 手套

One might argue that the label 〈dial.〉 is not informative enough, and that it would be preferable to specify the regions by their name. However, as far as L2 Chinese learners are concerned, they would show more interest in the meanings of those words than their regional origin.

\subsection{Classifiers in Chinese}

Classifiers (or quantifiers), which can be roughly divided into "sortal classifiers" and "measure words" (Ahrens and Huang 2016), often challenge L2 Chinese learners. Why does one say "一匹马" (a horse) and "一头牛" (a cow/bull) instead of *"一头马" and *"一匹牛"? It is difficult to deduce the usage of classifiers from a grammatical rule. Thus, L2 Chinese learners often wish to find information on classifiers from a dictionary.

Under the noun entries, GDCFC uses the sign $(\mathrm{Q})$ to specify the classifiers that they take. For example,

【秘诀】 mìjué (Q. 条) méthode $f$ secrète; recette $f$ secrète; secret $m$; truc $m$; clé $f \triangleright$ 成功的 secret du succès; recette de la réussite

【模型】móxíng (Q. 套、具、副) $\mathbf{1}$ modèle $m$, maquette $f \triangleright$ 飞机 modèle d'avion $\|$ 车身 $\sim$ modèle de carrosserie $\|$ 建筑 $\sim$ modèle d'un édifice || 缩比 modèle réduit, maquette réduite \|| 全尺寸 maquette grandeur réelle \|| 百分之一的 modèle réduit au $1 / 1002$ gabarit $m$; moule $m$; matrice $f$; forme $f \triangleright$ 石膏 $\sim$ moule en plâtre $\bullet \approx$ 模子 [múzi]

【蘑菇】 mógu (Q. 朵、片、棵) champignon $m$ comestible; champignon $m \triangleright$ 采 $\sim$ cueillir des champignons $\sim \sim$ 房 champignonnière $f$; meule $f$ (de terreau et de fumier)

In some entries, several interchangeable classifiers are given.

GDCFC also indicates those words or terms that can be used as classifiers with the sign $\langle$ q. $\rangle$, and at the same time exemplifies the contexts of usage in which they apply. For example,

泡 $^{3}$ pāo $\langle q$.$\rangle [s'appliquant uniquement à l'urine et aux excréments] \triangleright$ 撒泡尿 pisser (un coup); faire pipi \| 拉泡屎 aller à la selle \| 一泡狗屎 un étron de chien 
$匹^{2}\left({ }^{*} \mathcal{R}^{\Theta}\right)$ pǐ $\langle$ q. $\rangle$ (1) [s'appliquant au cheval, à l'âne, etc.] $\triangleright$ 一匹马 un cheval ||两匹骡子 deux mulets || 100匹马的马群 un troupeau de chevaux de cent têtes 2 [s'appliquant à la pièce ou au rouleau d'étoffe] pi, 1 pi $=50$ ou 100 chi (尺*) $\triangleright$ 一匹布 une pièce d'étoffe; un rouleau de tissu

【梭子 ${ }^{2} 】$ suōzi 1 cartouchière $f \mathbf{2}\langle$ q. $\rangle$ [s'appliquant à la cartouche] chargeur $m$; rafale $f \triangleright$ 打了一 $\sim$ 子弹 vider un chargeur, tirer une rafale

Apparently, such treatment will help L2 Chinese learners to have a clearer picture of specific classifiers preceding a noun.

\subsection{Formulaicity of some Chinese characters}

Whether one Chinese character can be freely combined to form a word is contingent upon morphological restrictions on it. Our experience in teaching Chinese as a foreign language shows that learners in the West have difficulty in distinguishing the stand-alone contemporary Chinese characters from those that are not. GDCFC indicates the Chinese characters, which are used only as morpheme, syllable or affix, respectively with the labels of $\langle$ morph. $\rangle,\langle$ syll. $\rangle$ or $\langle$ aff.〉. For example,

$Y\left({ }^{*}\right.$ 枒椏 $\left.{ }^{\Theta}\right)$ yā $\mathbf{1}\langle$ morph. $\rangle$ fourche $f$; bifurcation $f \triangleright$ 树Y fourche d'un

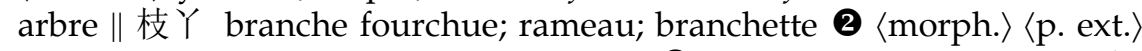
chose $f$ [objet $m$ ] en forme de fourche $3\langle$ morph.〉 $\langle$ dial. $\rangle$ fillette $f D$ 小Y petite fille; fillette 4 nom de famille

俩 (倆) liăng〈syll.〉伎[jị]俩・另见liă

老 ${ }^{3}$ lăo $\langle$ aff. $\rangle$ [ [devant certains noms désignant des personnes] $\triangleright$ 老百姓* $\|$ 老大娘* 2 [devant certains noms d'animaux ou de plantes] $\triangleright$ 老虎* $\|$ 老鹰* || 老玉米* 3 [devant un nom de personne monosyllabique] $\triangleright$ 老王 Lao Wang 4 [devant un numéral, de deuxième à dixième, désignant l'ordre des rangs d'âge] $\triangleright$ 她是老二。Elle est née la deuxième. || 王老三 Wang le troisième $\boldsymbol{5}\langle$ dial.> cadet(te) $a$; benjamin(e) $n \triangleright$ 老儿子 fils cadet; le benjamin de la famille \|老闺女 fille cadette; la benjamine de la famille

In this way, French learners of Chinese can gain useful information on the formulaicity of some Chinese characters, and reduce their errors as a result of arbitrary use of those characters.

\subsection{Flexibility of some Chinese characters}

In contrast to formulaicity, some Chinese words, which are composed of two or more characters, can be used in a "flexible" way. One may, where appropriate, detach a character (i.e. to insert a meaning unit), repeat certain characters (to strengthen the tone or to mitigate meaning), or even reverse the characters (to form another word or synonym). ${ }^{6}$ 


\subsubsection{Detachedness of some Chinese characters}

GDCFC marks such a headword with "//" in the middle of its phonetic notation, and offers examples of usage:

【搭伴】 dā//bàn $(\sim \varkappa)$ tenir compagnie (à qn); aller [partir] ensemble (à l'occasion); voyager en compagnie de (qn) $\triangleright$ 他也去北京, 你可以和他搭个伴几。Il va aussi à Beijing, tu pourras l'avoir comme compagnon de voyage. $\|$ 不与某人 fausser compagnie à qn

【带好九】 dài//hăor saluer qn de la part de...D 你回家时, 给叔叔带个好九。 Dis bonjour à mon oncle [Salue mon oncle] de ma part quand tu rentres à la maison.

\subsubsection{Repeated use of some Chinese characters}

GDCFC highlights the Chinese characters (morphemes) which can be used repeatedly. There are three types:

1) Type AB-AAB: One morpheme is repeated, e.g. 操心-操操心.

2) Type AB-AABB: Both morphemes are repeated, e.g. 安稳一安安稳稳.

3) Type AB-ABAB: The whole word is repeated, e.g. 反省-反省反省.

【操心】 cāo//xīn se préoccuper (de) v.pr; se soucier (de) v.pr; s'inquiéter (de) v.pr; se faire du souci; se donner du mal $\triangleright$ 你不必为那件事 $\sim \mathrm{Ne}$ vous embarrassez pas de cette affaire-là. || 他为孩子操碎了心。Il s'est fait beaucoup de souci pour ses enfants. || 我得为儿子的前途多操操心。Je dois me préoccuper de l'avenir de mon fils.

【安稳】 ānwěn (1 stable $a$; paisible $a$; solide $a$; ferme $a$; sûr(e) $a \triangleright$ 安安稳稳的生活 vie paisible || 睡得安安稳稳 dormir tranquillement || 船行 。 Le bateau s'avance doucement. (2 [en parlant surtout des enfants] sage $a$; posé(e) $a$; sérieu-x(se) $a$

【反省】 fănxǐng faire un retour sur soi-même; faire réflexion sur soimême; faire un examen de conscience $\triangleright$ 你是怎么犯错误的, 该好好 〜 。 Comment as-tu pu commettre une telle erreur? Tu dois faire un examen de conscience [effectuer un sérieux retour sur toimême].

\subsubsection{Reversed use of some Chinese characters}

GDCFC also marks the keyword entries in which both morphemes (characters) can be reversed (i.e. AB-BA).

This unique linguistic phenomenon in the Chinese language increases the learning burden on L2 Chinese learners. Although a general dictionary cannot deal with this problem in length, we believe that a simple indication will be 
useful to French users. In this dictionary,

1) the sign " $="$ indicates that the two morphemes are interchangeable, the word and the inverted keeping the same meaning $(\mathrm{AB}=\mathrm{BA})$;

2) the sign $" \approx "$ indicates that the two morphemes can be reversed in some cases, the inverted word keeping a close meaning; and

3) the sign " $\neq$ " indicates that the reverse word has a completely different meaning.

For example,

【脊背】jíbèi ( =背脊*) dos (d'un être vivant) $m \bullet=$ 背1(1)

【建构】 jiàngòu ( $\approx$ 构建*) [appliqué surtout à qch. d'abstrait] construire v.t; constituer v.t; instaurer v.t $\triangleright \sim$ 新的理论体系 établir un nouveau système théorique

【爱心】 àixin` ( $\neq$ 心爱*) (Q 份、番) cœur $m$ compatissant; amour $m$; affec$\operatorname{tion} f$

Obviously, such information given in GDCFC will help L2 Chinese learners to gain a better understanding of the flexibility of some Chinese characters, and use them correctly.

\section{Features designed for both groups of users}

GDCFC's design lies in its practical consideration of the needs of both groups of Chinese and French speakers: the needs of Chinese users producing French, and the needs of reception of Chinese by French speakers. We believe that this approach which is oriented to the needs of both groups of users is not necessarily opposed or contradictory, but is, to some extent, complementary. Even in the case of flexible use of Chinese characters as mentioned above, although the arrangement mainly aims to facilitate French speakers' comprehension, it can still help Chinese speakers to be sensitive to this type of linguistic phenomena.

The following design will benefit both groups of users at large.

\subsection{Indication of POS in context}

GDCFC attempts, whenever possible, to reflect the grammatical categories of Chinese headwords. The issue of indication of parts of speech (POS) of Chinese characters is, however, complex, and has provoked controversy among specialists. Sometimes, the POS indication in CCD and NDCC - the two authoritative monolingual Chinese dictionaries - does not properly correspond to the actual usage. Consider the word "免费" (free, gratis, free of charge). The two Chinese dictionaries categorize it into 励 (v.). Yet in natural context, "免费" is used more often than not as adjective or adverb. In addition, the two dictionaries sometimes contradict each other in POS indication. For example, while CCD 
labels "恼火" (irritated; be fuming at) with 国 (adj.), NDCC marks it as 动 (v.).

Since it is not easy to determine POS labels from existing Chinese dictionaries and the editorial team of GDCFC could hardly spare time to establish their own based on the words' usage patterns found in large Chinese corpora, it is advisable not to fall into the trap of POS indication. Instead, GDCFC illustrates the various usages of a headword with examples, and uses, if possible, translation equivalents of the same POS to reflect its grammatical categories. For instance,

【免费】 miăn//fèi dispenser (qn) des frais; gratuit(e) $a$; gratuitement $a d v$, gratis $a d v$; à titre gratuit loc.adv $\triangleright \sim$ 入场 entrée gratuite; entrée libre $\|$ 教育enseignement gratuit $\| \sim$ 学校 école gratuite $\| \sim$ 门诊 consultations gratuites $\| \sim$ 随带行李 bagages en franchise $\| \sim$ 为病人看病 traiter les malades gratis; soigner les malades gratuitement

【恼火】năohuǒ se fâcher v.pr; s'emporter v.pr; s'irriter v.pr; se vexer v.pr $\triangleright$ 我直说了, 你可别 。Je vais te parler franchement, seulement ne te fâche pas. \|| 这些话使他很 。Ces propos l'avaient exaspéré. \| 他慢条斯理, 叫我真 。Sa lenteur me fait bouillir. \| 他动不动就 。Il s'emporte facilement, même contre un rien. $\bullet \approx$ 恼怒(1)

【概述】gàishù (1 résumer v.t; exposer v.t sommairement $\triangleright$ 他向我们 了他的意图。Il nous a exposé sommairement ses intentions. 2 exposé $m$ sommaire; aperçu $m \triangleright$ 对当前形势作一个 donner un aperçu [brosser un tableau] de la situation actuelle

The corresponding French equivalents of "免费" as exemplified in context of usage show that this word can function as adverb, adjective and verb. In the same vein, those contextual equivalents illustrate the usage of "恼火" as either verb or adjective, and that of "概述" as either verb or noun.

\subsection{Equivalents in context}

Since cognitive (semantic, systemic or prototypical) equivalents are not easily available (Adamska-Sałaciak 2010, 2011), we argue that as an alternative, equivalents presented in a dynamic way can cater for users' reference needs. In the translation of entry words, especially in the rendering of idioms, GDCFC offers many explanatory and translational equivalents. A headword is first translated literally, then explained, and finally, a fixed French expression, which roughly corresponds to its Chinese counterpart but uses different lexical means and/or imagery, is given if available. All this would be accompanied by examples of usage. For instance,

【云开日出】yúnkāi-rìchū Les nuages se dissipent, le soleil réapparaît: revirement de fortune. | Le soleil dissipe les nuages. | Après la pluie vient le beau temps. (prov.) $\triangleright$ 他历经许多困苦, 今天总算 , 看到希望了。 Aujourd'hui, après maintes difficultés, les nuages se sont dissipés, le soleil réapparaît, et finalement il voit de l'espoir dans l'avenir. 
【游戏人生】 yóuxì- rénshēng jouer avec la vie; prendre la vie comme un jeu; mener une vie désinvolte; agir sans aucune contrainte $D$ 现在有些年轻人无所事事, 。De nos jours, certains jeunes mènent une vie oisive et pleine de désinvolture.

In our view, different types of equivalents at various levels can assist Chinese speakers in finding an appropriate French counterpart of a Chinese idiom, and assist French speakers in understanding the meanings of an idiomatic expression in Chinese.

\subsection{Semantic network of the nomenclature}

The nomenclature in a dictionary binds, as a whole, the semantic network of words. In GDCFC, synonyms or near synonyms of some headwords are thus offered. Unlike other dictionaries in which a static list of synonyms are given, GDCFC presents the synonyms in a typical context. For example,

【得当】 dédàng convenable $a$; adéquat(e) $a$; opportun(e) $a$; à point loc.adv, à propos loc.adv $\triangleright$ 采取 (适当*) 的措施 prendre des mesures convenables [opportunes] \|| 措词 (恰当*) s'exprimer en termes convenables [appropriés] $\|$ 回答 (恰当*) répondre de façon adéquate

【寄存】 jìcún mettre v.t à la consigne; mettre v.t en dépôt; consigner v.t; déposer $v . t \triangleright \sim$ (存放*) 行李 consigner ses bagages ...

Typical examples of usage will help users differentiate synonyms more accurately.

GDCFC also strives to cross-reference words or related terms. In this way, it has established a link between different words that belong to a system, and helps users to create a semantic network in their mental lexicon. For instance,

【霸王鞭1 $\bullet=$ 花棍舞、打连厢

【扛大梁】 káng dàliáng 〈fig.) assumer une grande responsabilité; jouer le rôle principal $\bullet=$ 挑大梁

【跟斗】gēndou $\langle$ dial. $\rangle \bullet \approx$ 跟头

【客舍】kèshè $\langle$ litt. $\rangle \bullet \approx$ 客店

【干租】gānzū louer $v$.t sans équipage; location $f$ sans équipage $\bullet \leftarrow$ 湿租

【倒果为因】dàoguǒwéiyīn inverser effet et cause; prendre l'effet pour la cause $\bullet \leftarrow$ 倒因为果

In the above entries, " $\bullet="$ is used to indicate synonyms; " $\bullet \approx$ " represents near

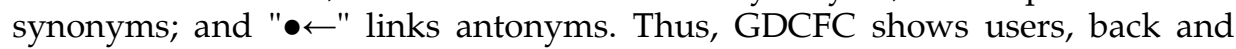
forth, useful links in the dictionary text. They learn not only a word or a single term, but also a series of words or related terms. To our knowledge, no ChineseFrench dictionaries, and even no general Chinese-English ones, have treated 
items in such a way. This dictionary might be the first attempt of this kind.

\section{Conclusion}

This dictionary has some distinctive features that other Chinese bilingual dictionaries (including Chinese-English/English-Chinese ones) are devoid of. Apart from an extensive and up-to-date lemma list, GDCFC pays special attention to the frequency, grammar and register of equivalents. It gives a lengthy treatment of formulaicity and flexibility of L2 morphology. It illustrates the POS as well as meaning of a headword in context of usage. It integrates the entry words into a semantic network by offering synonyms in context and cross-referencing related words.

The making of GDCFC has implications for the compilation of other lessresourced bilingual dictionaries. Dictionaries of this type often have to follow the design of bidirectional dictionaries ${ }^{7}$ (Hausmann and Werner 1991; Hannay 2003; Adamska-Sałaciak 2013), for "it is cheaper to produce one dictionary which will be sold in both markets than invest in two different ones" (AdamskaSałaciak 2013: 215). This does not mean that a bidirectional dictionary is confined to a skeleton structure, with only equivalents given. Far from it. A bidirectional dictionary can be "learnerized" in the way as a monodirectional bilingual dictionary does (Granger and Lefer 2016). In other words, such a dictionary can be designed to meet the needs of both groups of users in question. Priority is given to the morphological, semantic, syntactic and pragmatic points of an L2 lexical item with which learners may run into difficulty. It has to be admitted that some information in a bidirectional dictionary might look redundant to the group of L1 users, but that is a compromise before a monodirectional dictionary targeting a specific learner population is finally produced. A well-designed bidirectional dictionary can still boast some of its notable features.

\section{Endnotes}

1. It took such a long time to complete it, because a number of professors of French, who had been involved in the making of this dictionary, were dropped from the editoral team due to other commitments, and this project almost came to a halt when the editor-in-chief was diagnosed with cancer in 2008.

2. For instance, in 2018, this dictionary won the "Chinese Government Award for Publishing" the highest-level award in the Chinese publishing industry.

3. Apart from several pocket bilingual dictionaries, there are only 4 medium-sized ChineseFrench dictionaries published before 2014: Dictionnaire français de la langue chinoise (1976/ 1986/1994/1999), Dictionnaire chinois-français (1990), Nouveau dictionnaire pratique chinoisfrançais (1996), and Grand dictionnaire Ricci de la langue chinoise (2001), and most of them have not been updated.

4. This Chinese-French dictionary "aims to reflect today's Chinese language in all its dimensions, to integrate the needs of both Chinese and French speakers, and to show different translation options, ranging from a literal to an authentic idiomatic expression". 
5. See Section 4.2 for further discussion of the equivalency issue.

6. One major category of those Chinese words in flexible use is "separable word" or liheci (Packard 2016: 74-76).

7. The terminology is inconsistent in the literature. Landau (2001) and Atkins and Rundell (2008) use the term "bidirectional" dictionaries to refer to what Hausmann and Werner (1993), Hannay (2003) and Adamska-Sałaciak (2013) call "biscopal" (Lx-Ly and Ly-Lx) dictionaries.

\section{Acknowledgements}

This study was supported by the National Social Science Fund of China (Grant No. 15BYY062), and by the MOE Project of Key Research Institute of Humanities and Social Sciences at Universities in P.R. China (Project No. 17JJD740004). We would like to thank Professor Arleta Adamska-Sałaciak and Professor Danie Prinsloo for their valuable comments and suggestions.

\section{References}

\section{A. Dictionaries}

Académie française (Ed.). 1932-35. Dictionnaire de L'Académie française. Eighth edition. Paris: Hachette. Association Ricci pour le grand dictionnaire français de la langue chinoise and The Commercial Press Dictionary Research Centre (Eds.). 2014. Dictionnaire Ricci chinois-français. Beijing: The Commercial Press.

Dubois, J. (Ed.). 1980. Dictionnaire du français contemporain illustré. Paris: Larousse.

Huang, J.H. (Ed.). 2014. Grand dictionnaire chinois-français contemporain. Beijing: Foreign Language Teaching and Research Press. (GDCFC)

Institut Ricci (Ed.). 1976/1986/1994/1999. Dictionnaire français de la langue chinoise. Taipei: Institut Ricci-Kuangchi Press.

Jiang, L.S., J.C. Tan and R. Cheng (Eds.). 2012. Contemporary Chinese Dictionary. Sixth edition. Beijing: The Commercial Press. (CCD)

Larousse (Ed.). 2013. Le Petit Larousse illustré en couleurs. Paris: Larousse.

Li, X.J. (Ed.). 2014. Normative Dictionary of Contemporary Chinese. Third edition. Beijing: Foreign Language Teaching and Research Press, and Language and Culture Press. (NDCC)

Liu, J. and X.R. Liu (Eds.). 1996. Nouveau dictionnaire pratique chinois-français. Beijing: Social Sciences Academic Press.

Morvan, D. (Ed.). 1996. Le Robert illustré d'aujourd'hui en couleur. Paris: Le Robert.

Xu, J.Z. and L.G. Guo (Eds.). 1990. Dictionnaire chinois-français. Beijing: The Commercial Press.

\section{B. Other literature}

Adamska-Sałaciak, A. 2010. Examining Equivalence. International Journal of Lexicography 23(4): 387-409.

Adamska-Sałaciak, A. 2011. Between designer drugs and afterburners: A Lexicographic-Semantic Study of Equivalence. Lexikos 21: 1-22. 
Adamska-Sałaciak, A. 2013. Issues in Compiling Bilingual Dictionaries. Jackson, H. (Ed.). 2013. The Bloomsbury Companion to Lexicography: 213-231. London: Bloomsbury Academic.

Ahrens, K. and C.-R. Huang. 2016. Classifiers. Huang, C.-R. and D.X. Shi (Eds.). 2016: 169-198.

Atkins, B.T.S. and M. Rundell. 2008. The Oxford Guide to Practical Lexicography. Oxford: Oxford University Press.

Cowie, A.P. 1999. English Dictionaries for Foreign Learners: A History. Oxford: Clarendon Press.

Granger, S. and M.-A. Lefer. 2016. From General to Learners' Bilingual Dictionaries: Towards a More Effective Fulfilment of Advanced Learners' Phraseological Needs. International Journal of Lexicography 29(3): 279-295.

Hannay, M. 2003. Types of Bilingual Dictionaries. Sterkenburg, P. (Ed.). 2003. A Practical Guide to Lexicography: 145-153. Amsterdam/Philadelphia: John Benjamins.

Hausmann, F.J. and R.O. Werner. 1991. Spezifische Bauteile und Strukturen zweisprachiger Wörterbücher: Eine Übersicht. Hausmann, F.J., O. Reichmann, H.E. Wiegand and L. Zgusta (Eds.). 1991. Dictionaries. An International Encyclopedia of Lexicography: 2729-2769. Berlin/New York: Mouton de Gruyter.

Huang, C.-R. and D.X. Shi (Eds.). 2016. A Reference Grammar of Chinese. Cambridge: Cambridge University Press.

Huang, J.H. 2014. Jubi Weixia - Jian Ping Lishi Hanfa Cidian (A Review of Ricci de caractères chinois). Cishu Yanjiu (Lexicographical Studies) 202(4): 72-75.

Landau, S.I. 2001. Dictionaries: The Art and Craft of Lexicography. Second Edition. New York/Cambridge: Cam-bridge University Press.

Packard, J. 2016. Lexical Word Formation. Huang, C.-R. and D.X. Shi (Eds.). 2016: 67-80.

Svensén, B. 2009. A Handbook of Lexicography: The Theory and Practice of Dictionary-Making. Cambridge: Cambridge University Press.

Szende, T. (Ed.). 2006. Le français dans les dictionnaires bilingues. Paris: Honoré Champion.

Tarp, S. 2008. Lexicography in the Borderline between Knowledge and Non-knowledge: General Lexicographical Theory with Particular Focus on Learner's Lexicography. Tübingen: Max Niemeyer.

Xu, H. 2012. A Critique of the Controlled Defining Vocabulary in Longman Dictionary of Contemporary English. Lexikos 22: 367-381. 